The poison used was a mixture of colubrine and viperine venom. In the first instance a $x$ per cent. solution in sterile water was made. This solution was heated to $73^{\circ} \mathrm{C}$., and kept at that temperature for half an hour ${ }^{5}$; it was then flitered. 'When necessary a tenfold dilution of the original solution was used. The weights refer to the original dried venom. All injections were made into the marginal vein of the ear. It appears from this that 0.00035 gram per kilo. is a certain lethal dose; that 0.00030 gram per kilo. is a doubtful lethal dose, while o.00025 gram per
kilo. is a dose which a rabbit can survive under, a maximum non-lethal dose.

II.-Experiments to ascertain the amount of Venom which $1 \mathrm{c.cm}$. of Calmette's Serum is capable of Neutralising, the Venom and Serum being mixed in vitro.

In this series six lethal doses, namely, 0.002 gram per kilo., were mixed with varging amounts of serum. The mixture was allowed to stand at the laboratory temperature $\left(8^{\circ} \mathrm{C}\right.$.) for half an hour, and was then injected into the marginal vein of the ear. The venom was the same solution as was used in Series I. In calculating the amount of venom which the serum had been able to neutralise, or had failed to neutralise, the maximum non-lethal dose, namely, 0.00025 gram per kilo. was deducted in all cases.

\begin{tabular}{|c|c|c|c|c|}
\hline Animal. & $\begin{array}{l}\text { Weight in } \\
\text { Grams. }\end{array}$ & $\begin{array}{l}\text { Amount of } \\
\text { Venom per } \\
\text { kilo. of } \\
\text { Body } \\
\text { Weight in } \\
\text { Grams. }\end{array}$ & $\begin{array}{l}\text { Amount of } \\
\text { Serum per } \\
\text { kilo. of } \\
\text { Body } \\
\text { Weight in } \\
\text { c.cm. }\end{array}$ & Result. \\
\hline Rabbit_ז ... & 1280 & 0.002 & 1.50 & No symptoms. \\
\hline Rabbit.2 ... & 1705 & 0.002 & 1.25 & No symptoms. \\
\hline Rabbit $_{3} \ldots$ & 1980 & 0.002 & $x .25$ & No symptoms. \\
\hline 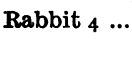 & 1977 & 0.002 & 1.00 & $\begin{array}{l}\text { Found dead four hours } \\
\text { afterwards. }\end{array}$ \\
\hline
\end{tabular}

From the above series we conclude that 1 c.cm. of serum fails to neutralise $0.002-0.00025$ gram $=0.00175$ gram, while 1.25 c.cm. can
neutralise this amount at least, namely, that $\mathrm{x} \mathrm{c.cm.} \mathrm{is} \mathrm{able} \mathrm{to} \mathrm{neutralise}$ 0.0014 gram at least.

III.-Experiments to ascertain the amount of Venom which $1 \mathrm{c.cm}$. of Serum $i$ capable of Neutralising, the Serum being Iniected five minutes before the Venom.

Six lethal doses of venom were used as before. Injections were made into the marginal veins of the ears.

\begin{tabular}{|c|c|c|c|c|}
\hline Animal. & $\begin{array}{c}\text { Weight in } \\
\text { Grams. }\end{array}$ & $\begin{array}{l}\text { Amount of } \\
\text { Venom per } \\
\text { kilo. of } \\
\text { Body } \\
\text { Weight in } \\
\text { Grams. }\end{array}$ & $\begin{array}{c}\text { Amount of } \\
\text { Serum per } \\
\text { kilo. of } \\
\text { Body } \\
\text { Weight in } \\
\text { c.cm. }\end{array}$ & Result. \\
\hline Rabbit 1 ... & 1150 & 0.002 & $2 . \infty 0$ & No symptoms. \\
\hline Rabbit $2 \ldots$ & 1290 & 0.002 & 1.50 & $\begin{array}{l}\text { Ill for } 2 \text { days ; lost } x 6 \text { grams } \\
\text { weight. }\end{array}$ \\
\hline Rabbit $3 \ldots$ & 1050 & 0.002 & 1.25 & $\begin{array}{l}\text { Very ill for } 2 \text { days; lost } 40 \\
\text { grams weight. }\end{array}$ \\
\hline Rabbit $4 \cdots$ & 1700 & 0.002 & 1.25 & $\begin{array}{l}\text { Very ill for } 2 \text { days; lost } 85 \\
\text { grams weight. }\end{array}$ \\
\hline Rabbit $5 \ldots$ & 1400 & 0.002 & $1 . \infty 0$ & Died in 60 minutes. \\
\hline Rabbit $6 \ldots$ & 2490 & 0.002 & 0.50 & Died in 25 minutes. \\
\hline
\end{tabular}

The results obtained from this series are practically the same as from Series II. It will be noticed that the rabbits Nos. 2, 3, and 4 showed marked symptoms and were ill for some time, while the rabbits in Series II which received corresponding amounts of venom and serum, mixed and kept for half an hour in vitro, showed no symptoms. This, perhaps, may be explained by the fact pointed out by Martin and Cherry $^{\circ}$ that, owing to the large molecular size and complexity of these substances, a certain interval of time must elapse before any chemical reaction is complete between them. During this interval an amount of venom sufficient to give rise to some symptoms of poisoning may pass into the central nervous system.

$$
\text { NOTE AND REFERENCES. }
$$

1 Ann. de l'Inst. Pasteur, 1897, p. 225 . 2 Intercolonial Medical Journal of Australasia, August 2oth, 1897. ${ }_{3}^{3}$ Ibid., April 2oth, 1898. 4 BRITISH MEDICAL JoURNAL, 1895, p. 1310; and r896, p. 957. 5 The venom is heated to coagulate a coagulable proteid, which is then filtered out. It is the non-coagulable residue which Calmette uses to immunise his horses. The coagulable proteid has been proved to destroy the blood corpuscles, and to produce intravascular clotting if it reaches the circulation rapidly. The non-coagulable proteid affects principally the central nervous system, 6 BRITISH MEDICAL JoURNAL, 1898, p. 1120. 7 Caimette, Le Venin des Serpents, p. $25 .{ }_{8}^{8}$ Loc. cit., p. I8. 9 Loc. cil., p. 26.10 BRITIS Medical JouRNaI, 1896, p. 957. il Calmette, le Venin des Serpents, p. ${ }_{3} 6$.

\section{A CASE OF GENERAL PARALYSIS OF THE INSANE IN A CHILD,}

IN WHICH A GALL STONE WAS FOUND AFTER DEATH. BY

JOHN THOMSON, M.D., and D. A. WELSH, M.D.,

$$
\begin{gathered}
\text { F.R.C.P.Edin., } \\
\begin{array}{c}
\text { Extra Physician to the Royal } \\
\text { Hospital for Sick Children, } \\
\text { Edinburgh. }
\end{array}
\end{gathered}
$$

Aцтнолgн a considerable number of cases of juvenile general paralysis have now been reported, ${ }^{2}$ it seems worth while to put another on record, as there is still much to be learned about both the diagnosis and the pathology of the disease. The occurrence of a gall stone in a young girl is also a matter of sufficient rarity to merit description.

The patient (I. T.) referred to in the following notes was between $10 \frac{1}{2}$ and i 1 years of age when she was first recognised as having symptoms of mental disease ; and she died at the end of her $x$ th year.

Family History.-The parents are strong, sober, and apparently healthy people; they are not at all nervous, and both come of unusually healthy and long-lived families. They have had seven children, of whom the patient is the second. The first, third, fifth, and sixth children, who are all alive, have shown distinct signs of congenital syphilis. The fourth child died, when 9 weeks of age, of bronchitis; the seventh is still an infant, and has had no specific symptoms. There have been no miscarriages.

Previous Health.-The mother has no recollection of the patient's having suffered from snuffles or a rash in infancy; but as she made the same statement with regard to a younger child whom I attended for weeks with these symptoms present, her memory is evidently not to be trusted to. When $4 \frac{1}{2}$ years old the patient developed a squint, which was operated on nine months later. About the same time she began to suffer from severe and frequent headaches. When $9 \frac{1}{2}$ years of age she was brought to the Sick Children's Hospital on account of her headaches, which were especially severe at night. She was found to have extensive patches of choroidal atrophy in both eyes. Her headaches were greatly relieved by iodide of potash. At this time she seemed in other respects a healthy, well-nourished, and intelligent child. She had had no serious illness of any kind, and had never suffered from jaundice nor from any severe dyspeptic'disturbances.

Present Illness. - When she was between $10 \frac{1}{2}$ and 11 years of age it was observed that she was not improving in her school work, and seemed to be getting stupid and irritable at home. No further change was noted in her mental condition until she was about 12 , when fits set in, and she became steadily less intelligent. Her speech was characteristically affected by the time she was $12 \frac{1}{2}$ years of age, and her knee-jerks were greatly exaggerated when she was i3 years of age. When about 14 years of age she had several distinct hallucinations. Between is and is years of age she became unnaturally fat, but afterwards she steadily emaciated. The fits continued at varying intervals during her whole life. Six months before her death she had an attack of subacute periostitis over the right tibia, which was greatly relieved by iodide of potash. She died in a state of extreme debility of mind and body, aged 16 years and in months (May $3 \mathrm{rd}, 1898$ ).

The main clinical features of the case may be summarised as follows :

Appearance, Growth, Etc.-When first seen, the child was well-nourished and of fairly normal size and appearance. Her cranium was well-formed, but the palate was high and saddleshaped. The upper central incisors were slightly pegged, but they were not typically deformed, and although there was some flattening of the bridge of the nose, and a slight lack of development of the upper jaws, such as is met with in congenital syphilis, there were no facial appearances which could be regarded as pathognomonic of that disease. The main indications of specific disease were the choroidal patches, which were present in both eyes from the beginning of the illness, and the subacute periostitis of the right tibia, which set in shortly before death. Between her eleventh"and fourteenth year the child grew very fat, so that she developed a 
marked double chin, and her abdomen was prominent and globular. After 14 years she gradually lost flesh, and during the last six months of her life she was extremely emaciated, and suffered from bedsores. After the mental symptoms began she grew very little in stature, so that at 15 she did not look more than 12 years old. Her mammæ remained quite undeveloped, and she never menstruated. During life no abnormality was discovered in theabdominal or thoracic organs.

Sensory and Reflex Functions.-As already mentioned, the child had suffered

from severe head-

ache from the time

she was 5 years old

and recurrent

headache was a

prominent feature throughout the whole illness. It was complained of at the onset of the fits and after they passed off, as well as frequently during the intervals. During the last year of her life she sometimes complained of severe abdominal pain. No other disturbance of sensation was discovered. For two years before she died she suffered much from incontinence of urine and fæces. The pupils reacted very imperfectly both to light and accommodation, and, after the mental symptoms began, they were for a long time distinctly irregular in contour ; the left was constantly the larger. No change wasobservedin the superficialreflexes, and facial irritability, although frequently examined for, was never found. The kneejerks were increased from the onset of the mental symptoms, and became more so during the last few years. No ankle clonus was obtained untilwithin a year of her death. Motor Symptoms. -The tongue was tremulous when protruded after

the first fit, and it became gradually more so towards the end. There was no distinct tremor of the hands at first, but they soon became so unsteady that she could not knit nor button her boots. Her writing, although it got rapidly very irregular, was never very characteristic. At the time the fits began she walked very clumsily as if her joints were stiff, and keeping her feet far apart. Her movements became gradually less active, and, when $13 \frac{1}{2}$ years old, she could no longer go downstairs without help. At 15 years she could still stand and walk alone, but she was unable to rise if laid down on the floor, and could not get into bed without assistance. When $16 \frac{1}{2}$ she could no longer stand alone and had to be carried about. Her speech was quite characteristically slurred when she was $12 \frac{1}{2}$ years old, and it got slowly worse. Before her death it was difficult to understand anything she said.

Convulsive Seizures.-The first fit occurred at the beginning of her $13^{\text {th }}$ year. She seemed to feel dazed, bent her head and

body backward until she would have fallen had she not been supported and cried " $\mathrm{My}$ head, my head," before she became unconscious. During the seizure the right forearm was extremely pronated, and it was weak for some days after. The other limbs seemed not to be affected. For some days after this attack she spoke very indistinctly, and complained of headache.

There was an interval of between ten and twelve weeks between each of the first five seizures. The attacks resembled one another in character,but there was more move ment in some than in others. Later they were less frequent, but rather more severe in their symptoms. When she was about 15 years old the attacks becam $\theta$ more frequent, but they were only occasionally severe in character. Most of them consisted merely in short periods of unconsciousness, in which she fell backwards if not supported. The seizures rather increased in severity during the last six months of her life, and oneside(sometimes the right and sometimes the left) was often noticed to be weak for some days after one of them. On one occasion a temporary squint was seen, and on another there was twitching of one upper eyelid. Mental Symptoms.-When 10 years old the patient was thought by her parents and teachers to be of ordinary mental capacity. At school she was in the Third Standard, along with girls of her own age, and at home she was very docile, amiable, and helpful. Towards the end of her inth year she was noticed to be getting gradually stupid, both in her schoolwork and at home. When she was $11 \frac{1}{2}$ she was still able, 
however, to take the younger children out to play, and to sweep the floor and otherwise help in household work. A year later she was quite unable to do any work except to go a simple errand. At this time, if allowed, she spent all her day playing with beads, talking to herself at the same time, and she got so absorbed in this occupation that she would get up with the daylight to begin it, and seemed to grudge the time for her meals. She was also very irritable with the younger children, and would beat them if they touched her beads. Her memory for certain things was long retained. At I $2 \frac{1}{2}$ she could still repeat those parts of the multiplication table that she had learned, although she was quite unable to do very simple sums. At I3 she still remembered hymns which she had been taught long before, but her mental powers rapidly deteriorated after this time. Within a few days of her death she seemed to recognise old friends, although she appeared to take little notice of surrounding things. When about 13 years of age she would constantly imagine that there was someone at the house door, when there was not, and would run to open it. She also insisted that some of her beads had got inside her pillow, and wanted to have it cut open to find them. When between 13 and 14 years of age she had various hallucinations. She often said she saw an elephant at one corner of her bed, and sometimes she pointed to what she thought were men in an empty room....... As the disease progressed the hallucinations became less distinct, but when between 14 and 16 she used to talk for hours to the pictures on the walls as if they were people.

The Course of the Disease was a steadily downward one: There was always an aggravation of the symptoms for some time after each fit or set of fits, and a slight degree of improvement was sometimes noticed at first, if a long period were passed without any seizures. On the whole, however, there was never any real improvement.

\section{Pathological Report.}

External Appearances.-Extreme emaciation; lower limbs rigidly flexed from permanent contracture of muscles; large bedsore over left trochanter, two smaller ones over right iliosacral joint ; mammæ quite undeveloped; pubic hair scanty.

HEAD.

Scalp not unduly adherent; calvarium irregularly thickened and condensed; dura mater thickened, and adherent at intervals to cranium. No trace of any subdural membrane formation; sinuses healthy. Excess of cerebrospinal fluid (over 3 ounces) at base of brain and in widened sulci of vertex. Pia arachnoid showed great venous engorgement, and was opaque and milky-looking from general chronic thickening. Tips of temporo-sphenuidal lobes were adherent to dura mater, and there were adhesions between frontal lobes in the median fissure. The pia mater was everywhere adherent to the brain, and could not be stripped off without laceration of superficial cortex.

Brain.-The cerebral convolutions were greatly atrophied, being small, narrow, and separated by dilated sulci. Atrophic changes were general, but most marked in frontal and parietal regions of each side. On section the cortical grey matter was found to be extremely atrophied, its layers indistinct, and its consistence tougher than nornal. The white matter showed irregular patches of congestion and increased toughness. The basal ganglia were also congested. The lateral ventricles were somewhat dilated, and their ependyma showed fine scattered granulations; more numerous and more prominent granulations were present in the fourth ventricle. The choroid plexus showed no obvious change.

Microscopic sections of the cortex from various regions showed changes characteristic of general paralysis in the nerve cells, in the neuroglia, and in the vessels. The nerve eells were greatly diminished in number, the majority having completely disappeared. Those still persisting were for the most part small, atrophied, and degenerating. The neuroglia showed very extensive proliferative overgrowth $(a)$ in the outermost layer of the cortex, producing a dense superficial felting; (b) in the white matter, especially at its junction with the grey; (c) throughout the whole extent of the grey matter, a less common site, so that numerous proliferated neuroglia cell's with hypertrophied branching processes occupied the place of the atrophied nerve cells. The medium-sized intracerebral vessels showed aggregations of leucocytes in the perivascular spaces, and the smaller vessels and capillaries marked hyaline thickening of their walls. The cerebellum showed similar but less marked changes.

Spinal Cord.-The spinal dura was thickened, and adherent to the pia mater from the first cervical to the fifth dorsal, and again over the seventh and tenth dorsal segments. The pia generally was thickened.

Thorax.-Thymus persisted as a thin flattened mass extending down to third costo-chondral articulation ; heart and pericardium healthy; lungs congested with scattered patches of recent broncho-pneumonia.

AвDOMEN.

The gall bladder (see figure, p. 785) was greatly distended with clear watery fluid. It formed an elongated, sausage-shaped tumour, measuring fully 5 inches in length and about 2 inches in transverse diameter. Its lower extremity projected 2 inches beyond the anterior free margin of the liver, and reached about an inch below the umbilicus, immediately to the right of the middle line. The cystic duct was dilated and tortuous, and towards its hepatic extremity a single gall stone was firmly impacted. This stone had a smooth surface and an ovoid outline: it measured $\frac{1}{2}$ by $\frac{3}{8}$ by $\frac{5}{16}$ inch in its various diameters. The central part consisted of a bilirubin chalk stone, around which subsequent deposits of calcium phosphate had occurred. Traces of cholesterin were present both in the original nucleus and in the later deposits. ${ }^{3}$

The liver showed scattered patches of perihepatitis over its surface. Its anterior margin was greatly thinned and atrophied over the enlarged gall bladder. Microscopic examination revealed a slight, diffuse intercellular cirrhosis, with denser irregular bands oi fibrous tissue passing in from the thickened capsule. Fatty degeneration and infiltration of liver cells also present.

The spleen showed marked perisplenitis with adhesions and thickening of capsule. Small dense fibroma on its surface.

The stomach, intestines, pancreas, kidneys, and adrenals showed no important lesion.

Pelvis.-Uterus infantile, measuring less than $1 \frac{1}{4}$ inch from fundus to os externum. Ovaries fairly large, but on microscopic examination were found to consist almost entirely of ovarian stroma, only degenerated and undeveloped follicles could be found; a few small cysts were also present. NOTES.

1 Dr. Thomson is responsible for the clinical, and Dr. Welsh for the pathological notes. $2 \mathrm{Dr}$. Charles Thiry in a recent thesis (Nancy, 1898) summarises 69 cases in patients under 20 years of age. $3 \mathrm{We}$ are indebted to Dr. T. H. Milroy, Lecturer on Physiological Chemistry in the University of Edinburgh, for his kindness in examining the composition of the Asylums, for valuable advice.

\section{ORGANO-THERAPY IN EXOPHTHALMIC GOITRE.}

By HENTON WHITE, M.D.DURH., F.R.C.S.ED., Birmingham,

The idea of administering gland extracts was first suggested to the writer by observing, post mortem, thymus glands of considerable size in two fatal cases of Graves's disease under the care of Dr. Foxwell at the Queen's Hospital, Birmingham.

It was desired to ascertain whether the enlargement of the thymus was an effort on the part of Nature to counteract the effect of excessive thyroid secretion, or whether it participated in producing the fatal results.

CASE I.-Mrs. B., aged 35, was first seen on January 25th, 1896, having marked proptosis, a soft and enlarged thyroid, and considerable tremor. She was easily excited. Her pulse was 120 , and she complained much of palpitation. Until March 7 th she was treated with digitalis, strychnine, and arsenic, without real improvement. On March $7^{\text {th }}$ the administration of suprarenal extract was commenced. She took four tabloids a day till June 6th, when her pulse was 128 , and she had not in any way improved. On June 6th the suprarenal extract was discontinued, and one tabloid of thymus extract was given three or four times a day. On July 4 th she sad she felt much better as regards palpitation; her neuralgia, from tremor was scarcely noticeable. The pulse-rate and exophthalmos were,

CASE II.-Miss S., aged 38, was first seen on August r3th, r895, when CASE II.-Miss S., aged 38, was first seen on August 13th, 1895, when She was treated until November 12 th, x895, with digitalis, iron, and 